\title{
Natural springs in northwest Saudi Arabia
}

\author{
Mohammed Abdullah Alsaleh ${ }^{1}$
}

Received: 7 February 2017 / Accepted: 20 July 2017 / Published online: 3 August 2017

(C) The Author(s) 2017. This article is an open access publication

\begin{abstract}
Several springs have been known in Saudi Arabia for hundreds of years on which many old settlements were dependent for both domestic uses and irrigation purposes. However, by the late 1980s, most of the springs in the central and eastern parts of the country dried up or ceased to flow as a result of extensive withdrawals of groundwater mainly for agricultural purposes. With the exception of some biological and religious studies, the previous studies on springs of Saudi Arabia have not mentioned any springs in the northwest region of the country. Therefore, the objectives of this study are to carry out a preliminary inventory to identify as many as possible of unrecognized springs in the northwest region of Saudi Arabia, to provide a scientific description and explanation of the current conditions of the identified springs, and to infer the spring flow sustainability. This study has identified, located, measured, and described a total of nine springs in the region.
\end{abstract}

Keywords Saudi Arabia - Tabuk Province - Midyan region • Water resources $\cdot$ Spring

\section{Introduction}

The geological structure of Saudi Arabia consists of two major geological parts. The western section is mainly composed of ancient igneous and metamorphic rocks and is called the Arabian Shield. The eastern section is sedimentary strata dip-

Mohammed Abdullah Alsaleh

masaleh@ksu.edu.sa

1 Department of Geography, King Saud University, Riyadh, Saudi Arabia ping east and northeast. Natural water resources in the Arabian Shield are limited and mainly dependent on current rainfall and wadi flow. Conversely, the eastern sedimentary part contains prolific aquifers with large volumes of fossil groundwater.

Saudi Arabia generally has scanty, highly irregular in time, and spatially very variable rainfall, and hence is not dependable. The climatic distribution of annual rainfall reveals that mean annual rainfall on the northwest region of the country ranges between 20 and $60 \mathrm{~mm}$ (The National Center for Atmospheric Research 2008). Besides, previous studies indicate that the northwest region is one of the driest areas in Saudi Arabia (Ministry of Agriculture and Water 1984; Bani-Domi 2005).

On the other hand, several springs have been known in Saudi Arabia for hundreds of years on which many old settlements were dependent for both domestic uses and irrigation purposes. However, by the late 1980s, most of the springs in the central and eastern parts of the country dried up or ceased to flow as a result of extensive withdrawals of groundwater mainly for agricultural purposes (Al Tokhais and Rausch 2008; FAO 2009; Kalbus et al. 2011). Groundwater levels and piezometric surfaces have fallen due to the rapid socioeconomic development of the country which began in the late 1970s. FAO (2009) mentioned that:

A typical example is the Al Hassa Oasis in the eastern province which draws on fossil water. Until the late 1970s, some 35 natural springs supplied the oasis and farmers used traditional irrigation practices to grow crops. To support the rapid expansion of commercial agriculture, tube wells were drilled in the oasis and by the mid-1980s the natural springs had dried up. The wells, which were originally artesian, now have water levels some 40-60 $\mathrm{m}$ below ground level - an average fall of $4 \mathrm{~m} / \mathrm{yr}$ (pp. 5-6). 
An appreciable number of studies have investigated springs in Saudi Arabia (Ministry of Agriculture and Water 1984; Bazuhair and Hussein 1990; Al-Hawas 2002; Al-Kahtani et al. 2007; Al-Naeem 2008; Al Tokhais and Rausch 2008; FAO 2009; Fathi and Al-Kahtani 2009; Kalbus et al. 2011; Aljohani 2014). However, some relatively recent previous studies contain misleading information giving an impression that the springs in eastern Saudi Arabia still discharging water. For example, Fathi and AlKahtani (2009) claimed that “Al-Khadoud's spring is one of the most important water resources in Al-Hassa Region and plays an important role in agricultural activities in the area" (p. 435). Another more recent example, Aljohani (2014) concluded that three flowing springs still exist in the Al Hassa oasis. Moreover, with the exception of some biological and religious studies (Ady 1991; Newton 1995; Potter 1999; Brown 2007; Hall et al. 2010; Llewellyn et al. 2010; Aloufi and Amr 2015), the previous studies on springs of Saudi Arabia have not mentioned any springs in the northwest region of the country.

Based on the average annual rainfall and the absence of information at the published specialized studies on natural springs in the northwest region of Saudi Arabia, one may get an immediate impression that renewable natural water resources are very scarce in the region. However, this is not completely correct because many Internet websites demonstrate notes and photos of springs in the northwest region of Saudi Arabia which were imaged by tourists, travelers, and amateur. For example, the notes of Ady (1991), on the talk given by Mr. Llewellyn on Jan 17, 1991, confirmed that the Wadi Qaraqir is having "permanent springs among the deep narrow canyons, one stream is $6 \mathrm{~km}$ long and seeps supporting hanging gardens of maidenhair fern" (p. 45). Besides, effective precipitation probably tends to be relatively high in the northwest region. It should be noticed that the evaluation of effective rainfall in the region is beyond the goal of this study. Indeed, vegetation covers and active wadi channels, in the region, indicate to the occasional occurrences of surface runoff and torrential flow. In addition, average rainfall has little meaning in desert areas because very high rainfall totals are sometimes recorded in individual storms (Goudie and Wilkinson 1977). Actually, the temporal distribution of rainfall in the country characterizes with a large number of low observations and infrequent but very significant extreme events (Jones 1981). In addition, geomorphological and geological characteristics are major factors that govern water movement and storage and consequently influence the effective precipitation in the region. Indeed, the Shield area of the northwest region was partially covered with permeable sedimentary rocks, weathered granite rocks, and alluvial deposits. Moreover, air temperatures and relative humidity characteristics in the northwest part of Saudi Arabia may influence evaporation rates in the region.

\section{Objectives}

Since the region characterizes with insufficient and irregular rainfall and limited water resources, no doubt that natural springs have been an important water source for wildlife habitats, domestic uses, and irrigation purposes. The study has three objectives. The first objective is to carry out a preliminary inventory (not an exhaustive search) to identify as many as possible of hitherto unrecognized springs in the northwest region of Saudi Arabia. The second is to provide a scientific description and explanation of the current conditions of the identified springs. The third objective is an attempt to infer the spring flow sustainability.

\section{Data and methodology}

The main task of this study was a contribution to fill the major gap of information on springs in northwest Saudi Arabia. Therefore, several steps were followed to achieve study objectives:

A- Collecting and obtaining literature on the topic and on the region.

B- Finding information (images, comments, articles, etc.) on the Internet Web sites: in fact, the idea of this paper has initially come from information on the Web where many photos and comments from tourists, travelers, and amateur confirming that northwest Saudi Arabia is having natural springs.

C- Acquisition of rainfall data, geologic maps, and topographic maps from governmental establishments.

D- Downloading multi-temporal Landsat images and ASTER digital elevation models (DEM) from USGS Web sites (https://glovis.usgs.gov; https://earthexplorer. usgs.gov). Multi-temporal Landsat images were mainly used to monitor changes either in cultivated areas that depend on water flowing from a spring (palm groves) or in vegetation covers associated with water availability of springs (wetland plants) as indicators of the of springs flows sustainability across the past few decades. The used Landsat images are MSS path 187 row 040 acquired Sept 15, 1972; TM path174 row 040 acquired Jul 29, 1987; ETM+ path 174 row 040 acquired Sep 07, 1999; OLI path 174 row 040 acquired Sept 14, 2016; MSS path 185 row 041 acquired May 05, 1973; TM path 173 row 041 acquired August 31, 1990; ETM+ path 173 row 041 acquired Oct 05, 2000; and OLI path 173 row 041 acquired Sept 23, 2016. The selected images intended to be at the end of dry summer season as much as possible.

E- Processing and analyzing multi-temporal remote sensing images using ERDAS Imagine software and ILWIS 
software, including geometric correction, image subsets, image enhancements, and generation of NDVI images.

F- Accomplishment of interviews: To implement interviews of local people, most of villages in the whole region (Haqil, Ash Sharaf, Az Zaytah, Bir as Sidrah, Al Bad', Maqna, AlKhuraybah, Al Muwaylih, Duba, Shaghab, Shuwaq, Ad Disah, Al Badiah, and Abar Qana) were identified on topographic maps scale 1:500,000, taking into account to be geographically distributed as well as possible. Interviews with at least three different local men were carried out at each settlement in Aug 2009, Sept 2011, and Oct 2016. Besides, interviews with several spring visitors were performed at the site of each spring in Aug 2009, Sept 2011, and Oct 2016.

G- Implementing field measurements and descriptions: the field exploration and measurements were carried out during the dry summer season in Aug 2009, Sept 2011, and Oct 2016 to locate and record springs in the study area, to obtain multi-temporal measurements for monitoring changes in water quantities and qualities, to verify continuity of springs discharge, and to provide general description of springs physical characteristics. Water from gravity valley side springs in the region is made to flow through pipes at a height about $50 \mathrm{~cm}$ (Fig. 1). Therefore, discharge volumes of these springs were measured using plastic containers with known capacities. On the other hand, discharge volumes of gravity contact springs and artesian fissure spring were measured using float method. The flow rate, for each spring, was measured in the spring channel of concentrating discharge as near to the spring outlet as possible. For each spring in the region, an average of three measurements was taken. Besides, electrical conductivity (EC) for each spring was measured in situ using a WTW LF323 meter.

H- GIS analysis using ILWIS software.

I- Spellings (Romanization) of geographic places names in the region reported by previous studies were not unified. Therefore, in this study, the Romanization appeared on the official topographic maps that were used.

\section{Study area}

Northwest region of Saudi Arabia is administratively part of the Tabuk Province. It is located within $27^{\circ} 30^{\prime}$ to $29^{\circ} 30^{\prime} \mathrm{N}$ latitudes and $34^{\circ} 29^{\prime}$ to $36^{\circ} 45^{\prime} \mathrm{E}$ longitudes (Fig. 2). Traditionally, this region is known as Midyan (Midian or Madyan) and is bounded by the Hisma plateau from the east and by the Gulf of Aqaba and the Red Sea from the west (Brown et al. 1989). It should be mentioned that the Midyan region characterizes by its diversity of cultural heritage, history, and natural landscape.

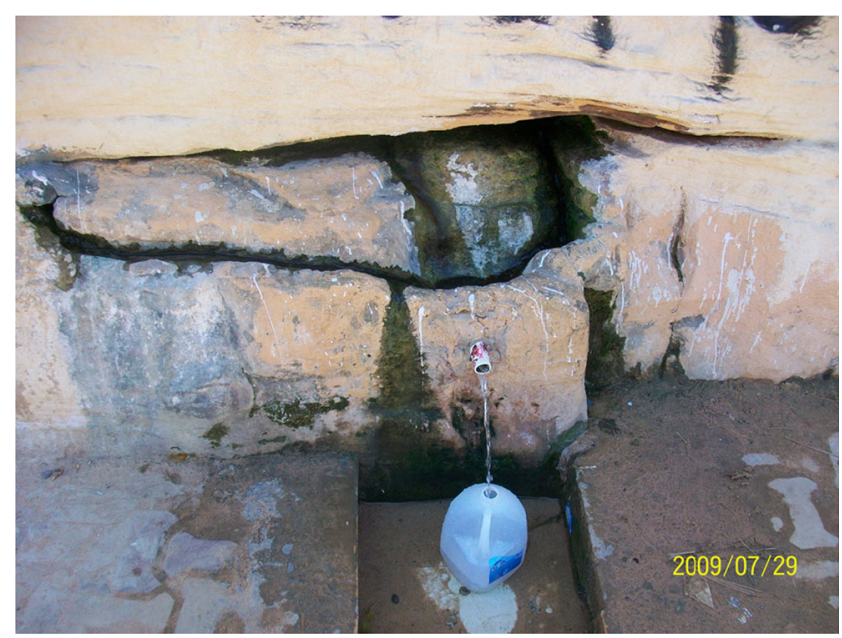

Fig. 1 The gravity valley side spring in Wadi Qaraqir (Ad Dysah)

Geologically, the western part of the Midyan region contains Proterozoic stratiform and intrusive basement rocks of the Arabian Shield which in some places overlaid by Mesozoic and Cenozoic sedimentary rocks, whereas the eastern part is composed of Paleozoic sandstones of the Hisma plateau (Trent and Johnson 1968). Llewellyn et al. (2010) reported that "the intensively dissected sandstone canyon lands are part of the Hisma plateau and overlie the igneous and metamorphic coastal hills of Madyan" (p. 38). Figure 3 is a geological map covering Wadi al Hamdah basin, Wadi Tayyib Ism basin, and Wadi Ad Disah basin that contain natural springs.

The surface elevation above mean sea level, in the study area, ranges from $0 \mathrm{~m}$ at the Red Sea coast to about $2400 \mathrm{~m}$ at the Jabal Al-Lawz $\left(28.6523^{\circ} \mathrm{N} 35.3317^{\circ} \mathrm{E}\right)$. Generally speaking, the region is mainly formed of mountains series and plateaus which are dissected by wadis. Mountains in Midyan represent the northern extension of the scarp mountains that extend to the east of the red sea. Brown et al. (1989) stated:

Farther north, another block is tilted upward along a series of faults that cut obliquely across the belt, forming the mountains of Ash Shifa', which lie in front of the Hisma Plateau and extend into Jordan. The highest point of Ash Shifa is Jabal al Lawz, 2,400 $\mathrm{m}$ above the Gulf of Aqaba. ... A series of knife ridges and canyons marks the southwestern fronts of each block. These southwestfacing slopes are in places transected by north-trending valleys which permit passage from one canyon to the next (pp. A172-74).

In fact, the Midyan region contains some of the most spectacular canyons in Saudi Arabia such as the canyon of Wadi Tayyib Ism, the canyon of Wadi Qaraqir, and the canyon of Wadi Ghamrah (Fig. 4). The region is drained by several wadi networks which mainly flow towards the Red Sea and the Gulf of Aqaba. 
Fig. 2 Location map of the study area. Source: General

Commission for Survey 2012

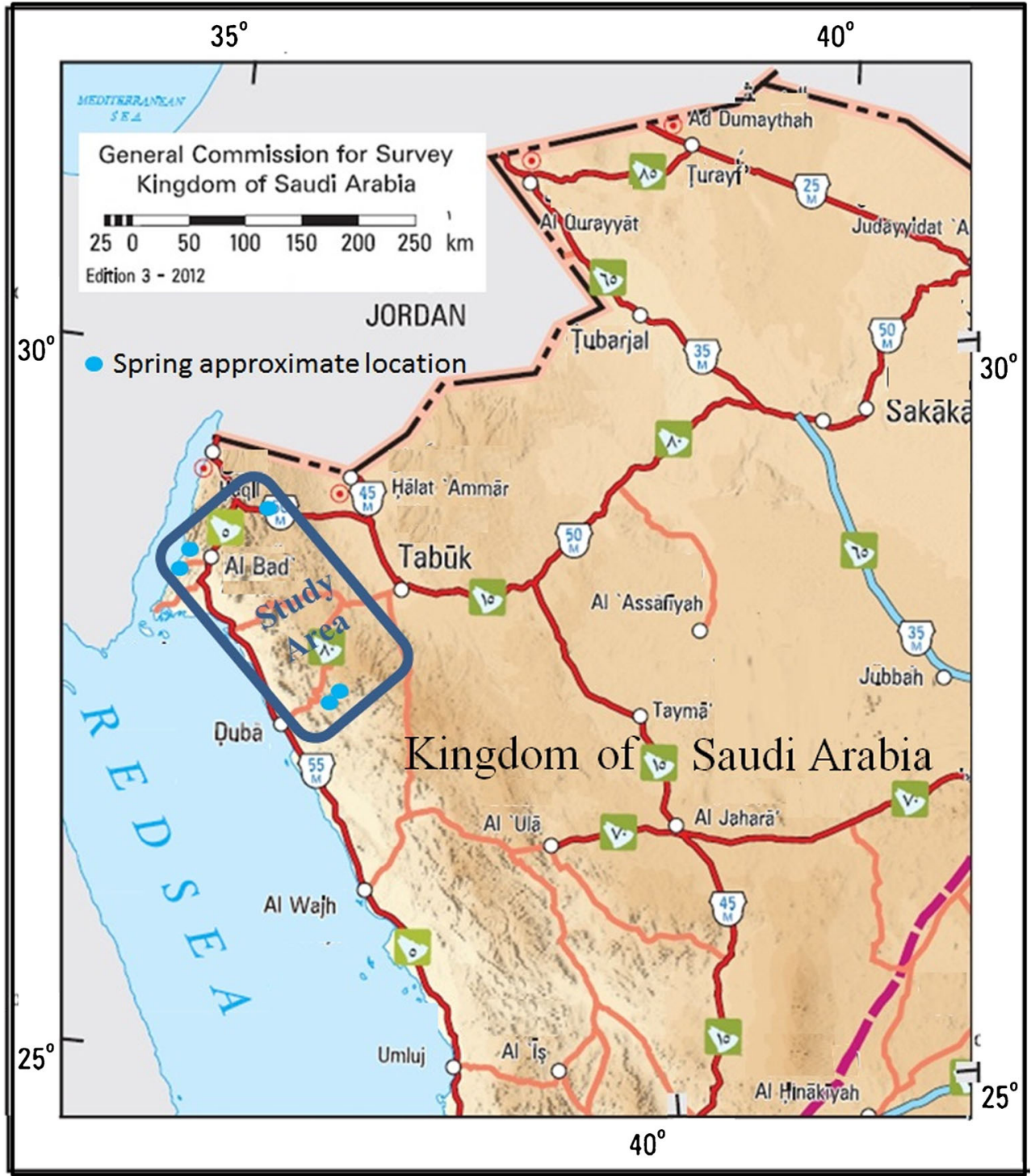

The climate of the region is characterized by hot dry summer and relatively cold winter. Precipitation mainly occurs irregularly during the fall, winter, and spring seasons. There are no precise rainfall data for the Midyan region. Therefore, measurements from the neighboring areas may give a general idea of the average annual rainfall in the region. The average annual rainfall at Shuwaq $\left(27.40^{\circ} \mathrm{N} 36.50^{\circ} \mathrm{E}\right)$ is at $47 \mathrm{~mm}$, at Duba $\left(27.35^{\circ} \mathrm{N} 35.70^{\circ} \mathrm{E}\right) 23 \mathrm{~mm}$, at Tabuk $\left(28.35^{\circ} \mathrm{N} 36.52^{\circ}\right.$ E) $31 \mathrm{~mm}$, and at Aqaba, Jordon $39 \mathrm{~mm}$ (Ministry of Water and Electricity 2000; Bani-Domi 2005; Almazroui 2011; Hasanean and Almazroui 2015).

Several traditional agricultural villages exist in the region such as Maqna, Al Bad', and Ad Disah. Agricultural fields are mainly irrigated by renewable groundwater. The main crops produced in the region are the dates, forage crops, fruits, and vegetables. However, due to the rapid increase of population in Saudi Arabia and changes in socio-economic patterns resulting from booming oil economy in the final quarter of the last century, some of the villages have expanded rapidly forming a town such as Al Bad'. Another traditional activity going on in the region is animal breeding namely sheep, goats, and camels.

\section{Results and discussion}

The survey to identify springs in the region was based on the comprehensive Internet searching which followed by interviews of local people and spring visitors. The Ain Musa Spring, the Wadi Tayyib Ism spring, and the Wadi Qaraqir springs have been initially recognized via Internet searches since 2009. On the other hand, interviews with local people helped to realize the Al Qattar spring at Az Zaytah and the two springs in Wadi Ghamrah (Fahad Alhuwati, personal communication, August 1, 2009; Abdullah Alatowi, personal communication, August 3, 2009). Concurrently, an interview with 


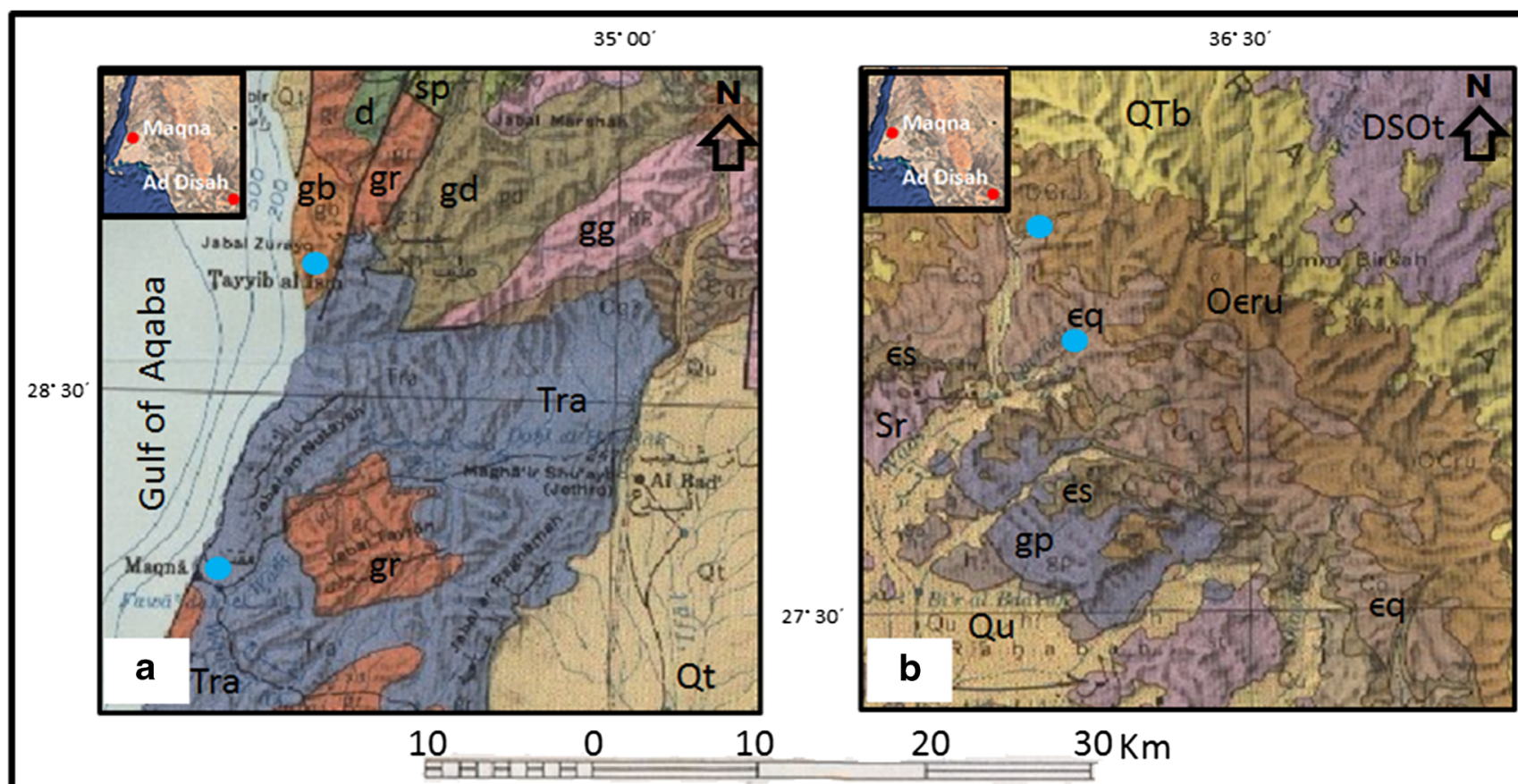

\begin{tabular}{|c|c|c|c|}
\hline - & Spring approximate location & & \\
\hline Qu & $\begin{array}{l}\text { Gravel, sand, silt, and clay: } \\
\text { wadi alluvium and costal saline } \\
\text { mud flat }\end{array}$ & d & Diorite \\
\hline Qt & $\begin{array}{l}\text { Terrace deposit: dissected alluvial } \\
\text { fans terraced wadi alluvium and } \\
\text { coralline limestone }\end{array}$ & $\mathrm{Sr}$ & $\begin{array}{l}\text { Shammar rhyolite: flows of } \\
\text { rhyolite, dacite, and adnesite }\end{array}$ \\
\hline QTb & $\begin{array}{l}\text { Basalt and andesite: mostly fissure } \\
\text { eruptions ranging in age from Late }\end{array}$ & gp & Granite or syenite: red or pink \\
\hline & Tertiary to Recent & & \\
\hline Tra & $\begin{array}{l}\text { Raghama formation: gypsum, } \\
\text { sandstone, limestone, and }\end{array}$ & gr & $\begin{array}{l}\text { Granite: red or salmon, course- } \\
\text { grained }\end{array}$ \\
\hline DSOt & $\begin{array}{l}\text { Tabuk formation: sandstone, } \\
\text { siltstone, and shale }\end{array}$ & gg & $\begin{array}{l}\text { Granite and granodiorite: } \\
\text { syntectonic type, }\end{array}$ \\
\hline OEru & $\begin{array}{l}\text { Ram and Umm Sahm sandstone: } \\
\text { continental in the lower part, }\end{array}$ & gb & Gabbro \\
\hline Eq & $\begin{array}{l}\text { Quweira sandstone: yellow or buff } \\
\text { medium grained }\end{array}$ & $\mathrm{sp}$ & Serpentinite \\
\hline ES & Siq sandstone: dark red & gd & $\begin{array}{l}\text { Greenstone: diabase, andesite, } \\
\text { and basalt, somewhat } \\
\text { metamorphosed to greenschist }\end{array}$ \\
\hline
\end{tabular}

Fig. 3 a Geological map of the Wadi al Hamdah basin and the Wadi Tayyib Ism. b Geological map of the Wadi Ad Disah basin. Source: Bramkamp et al. 1963

Mohammed Albluwi on October 14, 2016 assisted in knowing the Asaad spring, and he also mentioned that many seepages and small springs are available in the inaccessible upper reaches of Wadi Ghamrah stressing on the variations in their discharges from year to year.
This study has identified, located, measured, and described a total of nine springs (Table 1). In the western part of the region, two springs have been recorded which are Ain Musa Spring and Wadi Tayyib Ism spring, while six springs have been found in the eastern part of the region at Wadi Qraqir and 
Fig. 4 The canyon's end of the Wadi Tayyib Ism
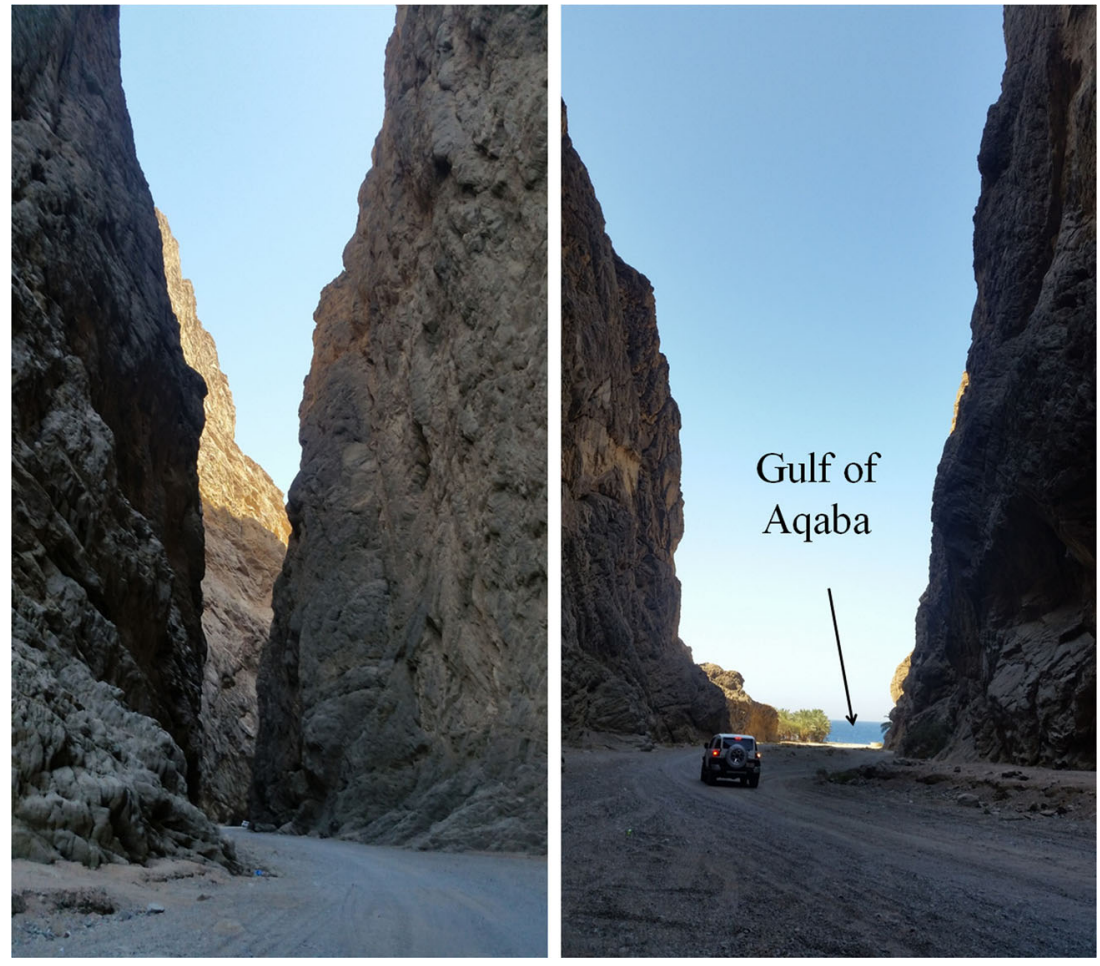

Wadi Ghamrah the two main branches of Wadi Ad Disah basin (three springs at Wadi Qraqir, two springs in Wadi Ghamrah, and one spring at a high point on the scarp of Hisma plateau at the most upper reaches of Wadi Qraqir). The springs in the northwest region of Saudi Arabia have been discussed as individuals or groups under the following four titles, starting with springs located along the eastern coast of the Gulf of Aqaba.

\section{Ain Musa (Moses) spring}

The Ain Musa Spring is located at Maqna town, i.e., at the lower reaches of Wadi al Hamdah basin. Trent and Johnson (1968) reported that Maqna town once was an ancient maritime port and capital city of the "Land of Midian." It was listed by Ptolemy that is one of the several "Mediterranean cities" in Arabia Felix" (p. 1). The spring pool geographic coordinates are $28^{\circ} 23^{\prime} 46^{\prime \prime} \mathrm{N} 34^{\circ} 45^{\prime} 03^{\prime \prime} \mathrm{E}$. About $1200 \mathrm{~m}$ to the southeast from the Gulf of Aqaba along the Wadi al Hamdah, the northern valley side slope rises abruptly forming a small sandy plateau, which is mainly sloping towards the northwest. The spring emerges on top of the plateau at a height about $50 \mathrm{~m}$ above sea level and about $40 \mathrm{~m}$ above the adjacent wadi channel bed. The distance from the spring pool to the adjacent wadi channel bed is about $105 \mathrm{~m}$ (Fig. 5). Based on field visits, it is clear that this plateau is mainly formed of sandstone and limestone. Actually, the geologic map of Al Bad' quadrangle, sheet 28 (Clark 1987), shows that the area of the Ain Musa spring is covered by Nutaysh formation of Raghama Group which composed of conglomerate, sandstone, marl, and limestone. It must be mentioned that this formation in the Maqna area is having other lithostratigraphic names used in previous works, for instance, Raghama formation (Brown et al. 1963; Trent and Johnson 1968; Brown et al. 1989) and Burqan formation (AlLaboun et al. 2014). Al-Laboun et al. (2014) stated that"

The sandstone of Burqan Formation is a part of sedimentary succession in the Midyan Basin, northwestern Saudi Arabia. The thick marine siliciclastic succession of this formation is well exposed in the west of Jabal Rughama (flanking the Magna Massif) and along the Gulf of Aqaba coast (north and south of Magna village) .... The Burqan Formation was deposited over the tectonically controlled Red Sea rift. The depositional system has been identified as a deep marine turbidite .... The Burqan Formation unconformably overlies the Tayran Group as well as the Proterozoic Basement. At the Jabal Al-Risha exposure, sandstone of the Burqan Formation conformably overlies the oyster-bearing carbonates of the Musayr Formation. The Burqan Formation is then unconformably overlain by anhydrite of the Kial Formation, a part of the Magna Group (p. 205).

Furthermore, the 1:250,000-scale geologic map of the Al Bad' quadrangle reveals that this formation extends mainly from Maqna town towards the northeast forming a series of mountains along the Gulf of Alaqaba called Jabal An Nutaysh. The maximum height of these mountains is about $500 \mathrm{~m}$ above sea level. 


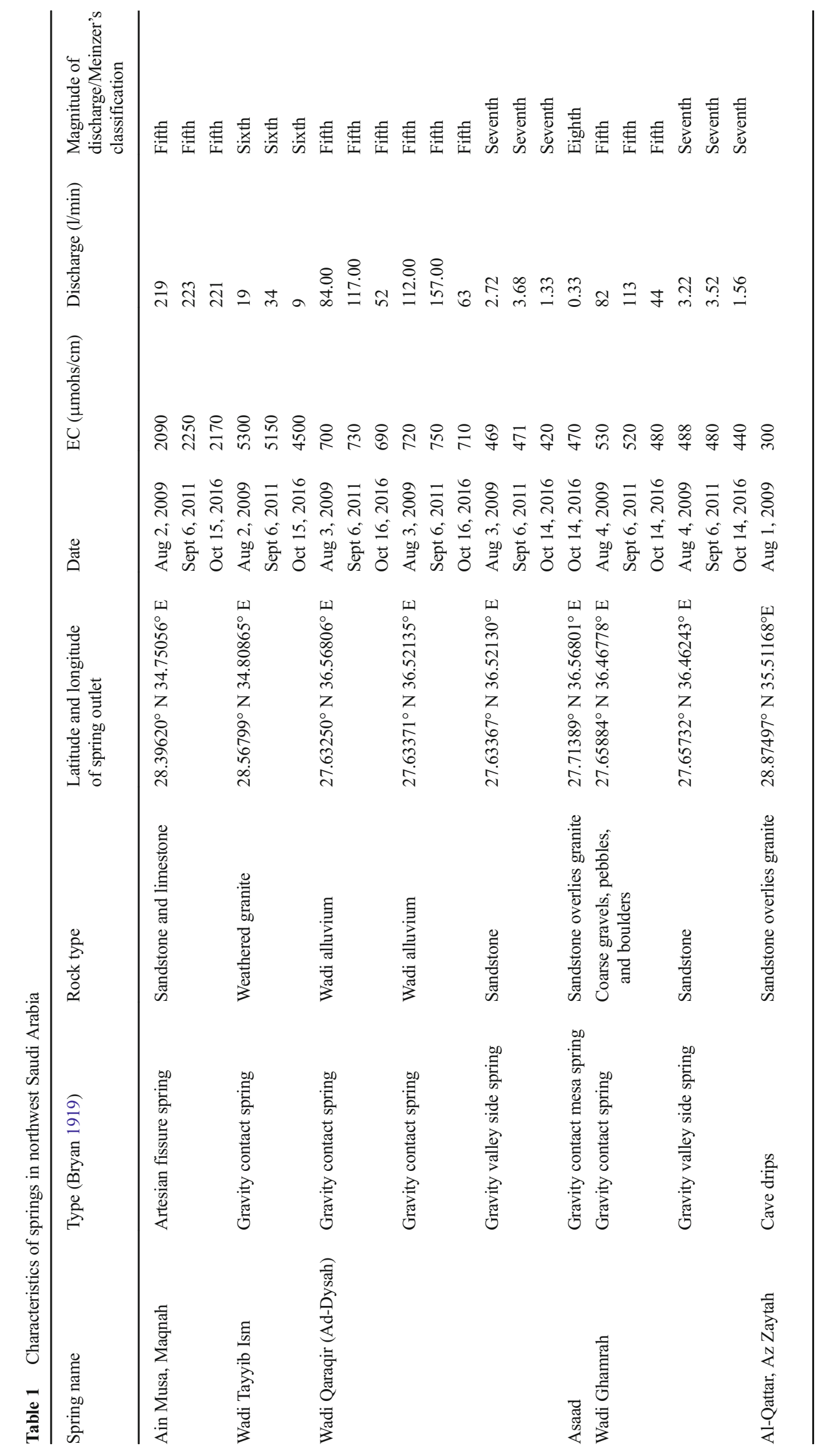




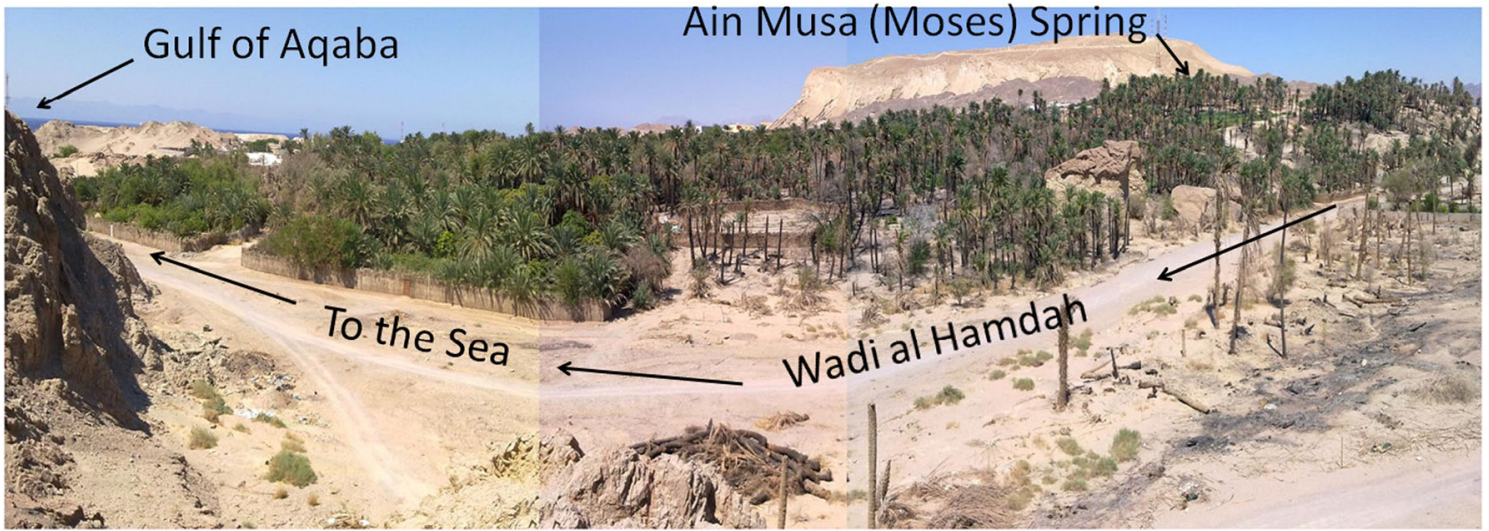

Fig. 5 Palm groves irrigated by the Ain Musa (Moses) spring

Previous studies on the Midyan region, northwest Saudi Arabia, pointed out that the common groundwater aquifers in the area are unconfined shallow aquifers of Wadi alluvium underlain with weathered bedrocks (Zumlot et al. 2016). Ghrefat et al. (2014) indicated that the depth of aquifers is $<60 \mathrm{~m}$ with shallow groundwater table. The aquifers in this area are mainly recharged from current irregular rainfall and runoff (Al-Taani et al. 2013). Definitely, the Ain Musa spring discharges fresh groundwater of an aquifer and studying the aquifer characteristics such as areal extent, thickness, water table depth or piezometric surface, and hydraulic properties is beyond the scope of this paper. Therefore, it is only an attempt to provide general information and modest explanation of the aquifer which supplies the Ain Musa spring with water. Although the valley side of the Wadi al Hamdah is an exposure of the southern end of the Nutaysh formation, the Ain Musa spring emerges at a height about $40 \mathrm{~m}$ above the adjacent wadi channel bed which is only about $105 \mathrm{~m}$ to the south of the spring pool. This fact excludes the assumption that the water feeding the Ain Musa spring is coming from a wadi alluvium unconfined aquifer. At the same time, it can be used as an indication that the Nutaysh formation is serving as an aquifer to supply this spring with water. Besides, the topographic position of the spring reveals that water supply of the spring comes from a confined aquifer. Therefore, the Ain Musa spring can be classified, based on the force causing the spring (Bryan 1919), as an artesian fissure spring.

It can be seen from Table 1 that only minor changes occurred of water quantity and quality measurements in the Ain Musa spring which were carried out 2009, 2011, and 2016. Average electric conductivity in the spring was about $2170 \mu \mathrm{mohs} / \mathrm{cm}$, and average discharge was about $223 \mathrm{l} /$ $\mathrm{min}$. The water of the spring has been used mainly to irrigate many small palm groves with a total area about $153,500 \mathrm{~m}^{2}$. The water of the spring, flowing under gravity from a higher level to a lower level through traditional ditches, has been used to irrigate these palm groves. During an interview conducted on October 16, 2016, Mr. Mohammed Alfaydi (one of the palm groves owners) stated that the farmers since several centuries have had a conventional systematic manner to manage, to share, and to distribute the water of the spring. He mentioned that the Gregorian calendar has been used to distribute the water of the spring equitably among the farmers.

Measurements of multi-temporal Landsat images indicated that total areas of palm groves were very similar in 1972, 1987, and 1999 (Fig. 6), where it was about 153,500 $\mathrm{m}^{2}$. This may indicate to the temporal consistency of water discharge from the spring. On the other hand, Landsat image acquired 2016 showed a decrease of about $40 \%$ in the total area of palm groves, where it was about $92,000 \mathrm{~m}^{2}$. Alfaydi (personal communication, October 16, 2016) pointed out that the discharge of the spring has never decreased and attributed the change in the total area of palm groves in the recent years to social and economic factors rather than discharge declining. He clarified that local people have been more educated and could easily find easier, more convenient, and more profitable jobs in governmental or private sectors. It should be noted that Saudi Arabia, in the final quarter of the last century, had experienced an enormous economic growth due to huge oil and gas revenues which resulted in changes in socio-economic patterns of the country. Besides, Mr. Alfaydi mentioned that the modest income of these small traditional farms and the better opportunity of working in governmental or private sectors have led to the lack of care to the palm groves. Therefore, the palm groves had two fires in the last few years, because of letting dry date palm fronds and fibers to accumulate in the palm groves.

\section{Wadi Tayyib Ism spring}

The Wadi Tayyib Ism spring is located in the lower reaches of Wadi Tayyib Ism drainage basin which flow in the Gulf of Aqaba. In fact, the lower reaches of Wadi Tayyib Ism form a granite canyon. Clark (1987), Hughes et al. (1999), and Tubbs et al. (2014) provided the most comprehensive description of the geology of the Midyan region. The 1:250,000-scale geologic map of the Al Bad' quadrangle (Clark 1987) shows that the rock bodies in the Wadi Tayyib Ism basin are made of Cenozoic 


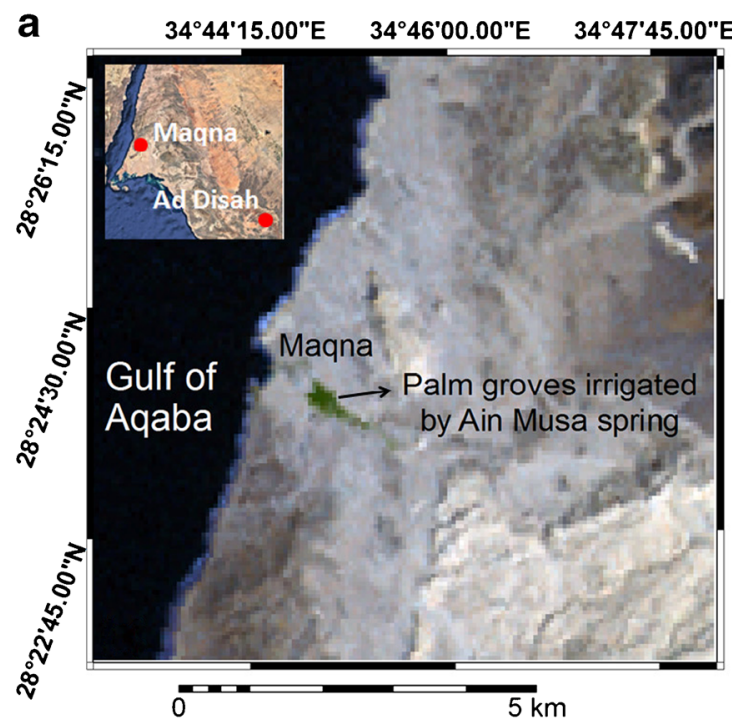

C $\quad 34^{\circ} 44^{\prime} 15.00^{\prime \prime} \mathrm{E} \quad 34^{\circ} 46^{\circ} 00.00^{\prime \prime} \mathrm{E} \quad 34^{\circ} 47^{\prime} 45.00^{\prime \prime} \mathrm{E}$

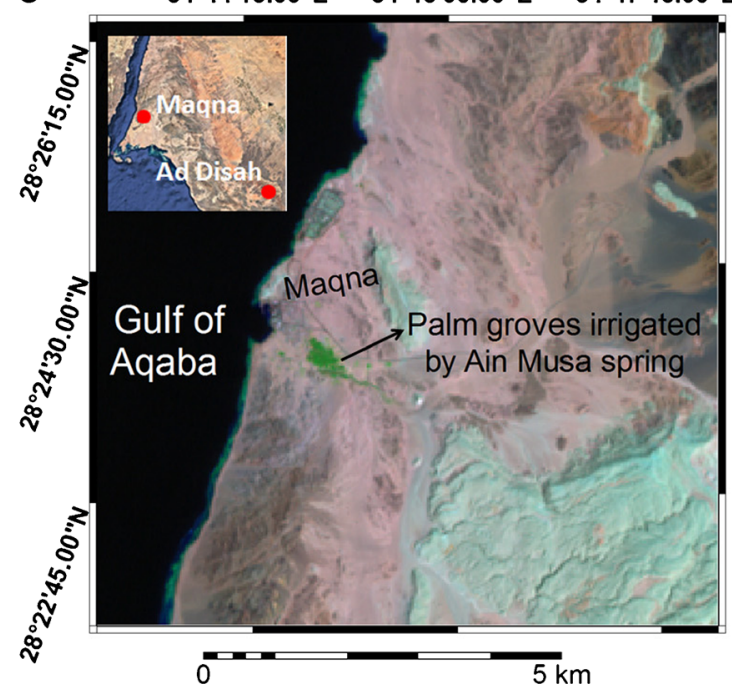

Fig. 6 Multi-temporal Landsat images showing palm groves (green color) irrigated by Ain Musa spring. a Landsat MSS imagery Sept 15, 1972 presented in semi-natural color composite. b Landsat TM imagery Jul 29, 1987 presented in false color composite (R 7, G 4, and B 2). c

sedimentary, Proterozoic stratiform, and intrusive rocks. In some places of the wadi basin, sedimentary strata overlie the Precambrian rocks. In fact, the area is covered by different types of rocks including diorite, gabbro, monzogranite, granodiorite, alkali granite, alkali quartz syenite, sandstone, and conglomerate.

At the outlet of the Wadi Tayyib Ism, mountains extend directly into the sea water forming the shoreline of the Gulf of Aqaba. The lower reaches of the wadi forms a magnificent narrow canyon extending upward from its outlet at the Gulf of Aqaba to about $2.5 \mathrm{~km}$ (see Fig. 4). Generally speaking, the canyon extends in a west direction towards the Gulf of Aqaba. The height of the gorge walls is about $300 \mathrm{~m}$ from the canyon's floor. The canyon floor is covered partially with medium gravels, and the bedrock exposes in many areas of the floor.
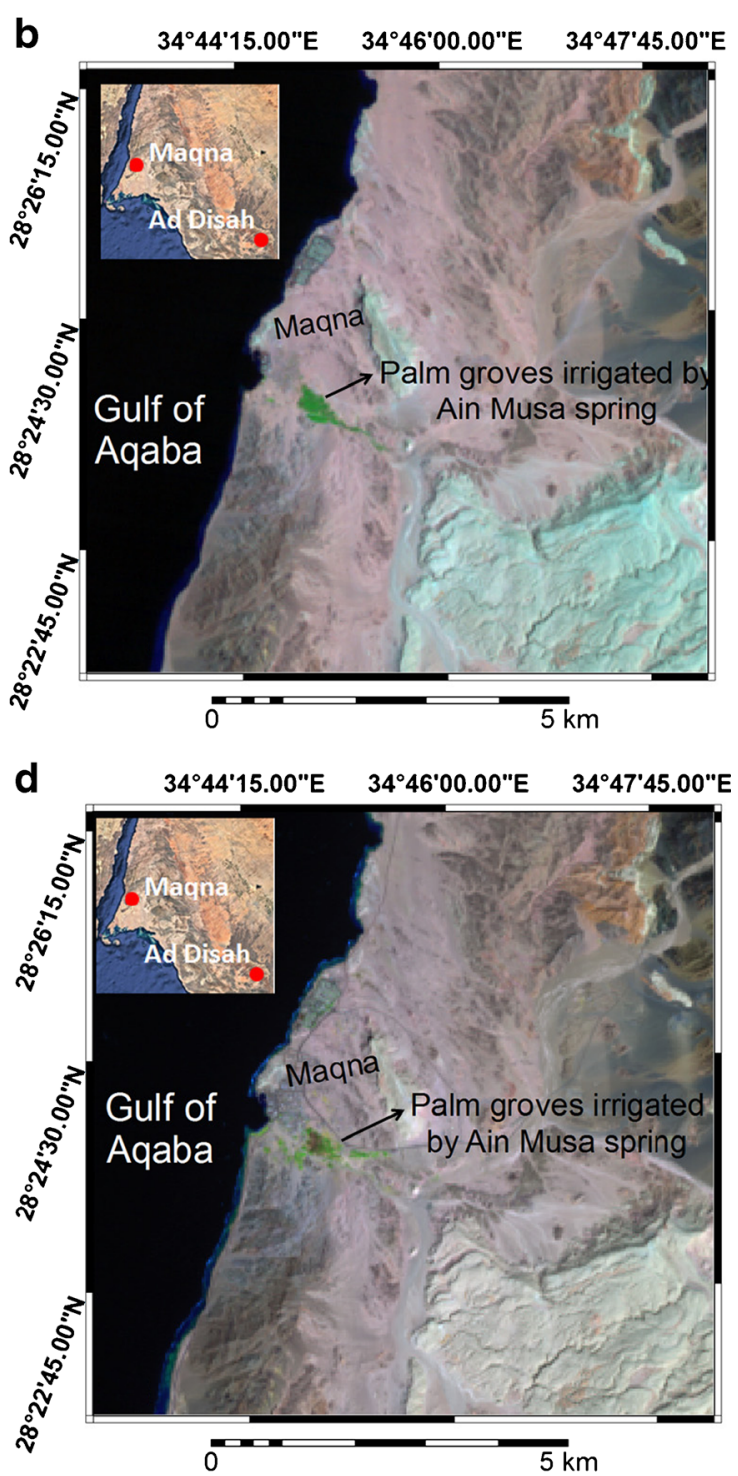

Landsat ETM+I imagery Sept 7, 1999 presented in false color composite (R 7, G 4, and B 2). d Landsat OLI imagery Sept 14, 2016 presented in false color composite (R 6, G 5, and B 3)

Actually, the coastal granite mountain range in the lower reaches is much higher than hilly land in the middle reaches of the basin. However, an impressive stream ravine has cut through this massive granite geologic block to find its way to the sea. The geologic map compiled by Clark (1987) shows that a Cenozoic sandstone layer overlies the Precambrian granite bedrock near the upper end of the canyon. Besides, geologic maps do not show any faults coinciding with the direction of the canyon. Therefore, one may argue that the drainage system in the Wadi Tayyib Ism established on the formerly overlying sandstone formation and inherited by the lower granite block forming a superimposed stream.

About $1600 \mathrm{~m}$ from the Gulf of Aqaba, the Wadi Tayyib Ism spring emerges from the streambed at $28.56799^{\circ} \mathrm{N}$ 
$34.80865^{\circ} \mathrm{E}$. In the two first field visits 2009 and 2011, the spring ran down continuously as a small stream for a distance about $1150 \mathrm{~m}$ to end at a natural pool excavated at granite rocks which are located at $28^{\circ} 33^{\prime} 40.98^{\prime \prime} \mathrm{N} 34^{\circ} 48^{\prime} 19.45^{\prime \prime}$ E. The discharges were estimated to be $191 / \mathrm{min}$ in 2009 and 34 1/min in 2011. From Table 1, it can be seen that the spring discharge is highly variable, where the discharge in 2016 represented only $26 \%$ of the discharge in 2011. In 2016, the natural pool was completely dry because the spring discharge was not reaching it. In fact, the spring discharge was estimated to be about $9 \mathrm{l} / \mathrm{min}$, and the spring stream had discontinuous flow for a distance about $620 \mathrm{~m}$. The flow discontinuity was because of average infiltration rates exceeded flow rates in some areas along this distance of the spring stream. The variations of the spring discharge may be attributed to the water recharge from precipitation and runoff at the wadi basin. On the other hand, electrical conductivity measurements of the spring were 5300, 5150, and $4500 \mu \mathrm{mohs} / \mathrm{cm}$ in 2009, 2011, and 2016, respectively. These measurements have shown that water quality of the spring varied from year to year. The EC in 2016 was about $15 \%$ less than the EC value in 2009 . The variations of water flows and EC values of the Wadi Tayyib Ism spring for the three different years can be easily seen in Table 1. Moreover, from a quick look at the EC values and discharge rates, one may realize that no relationship between water quantities and qualities of the spring.

\section{Wadi Ad Disah springs}

Ad Disah is an agricultural village located at $27.60447^{\circ} \mathrm{N}$ $36.42781^{\circ} \mathrm{E}$. This village exists at the confluence of three major canyons in the region. The Wadi Qaraqir and the Wadi Ghamrah are the main branches in the Wadi Ad Disah basin which drain a sandstone area of Jabal Qaraqir. The
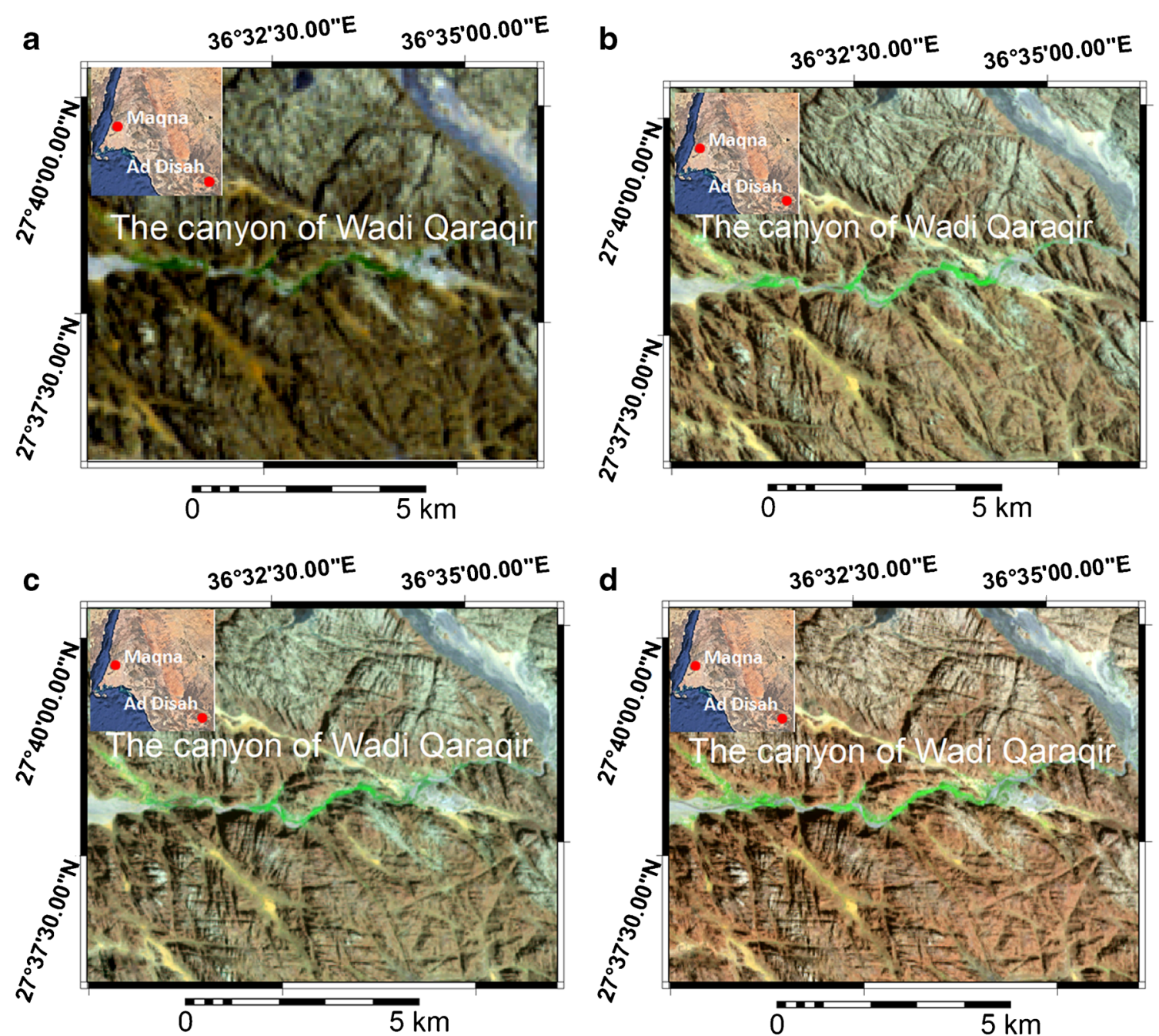

Fig. 7 Multi-temporal Landsat images showing vegetation cover (green color) in the canyon of Wadi Qaraqir. a Landsat MSS imagery May 5, 1973 presented in semi-natural color composite. b Landsat TM imagery Jul 6, 1987 presented in false color composite (R 7, G 4, and B 2). c

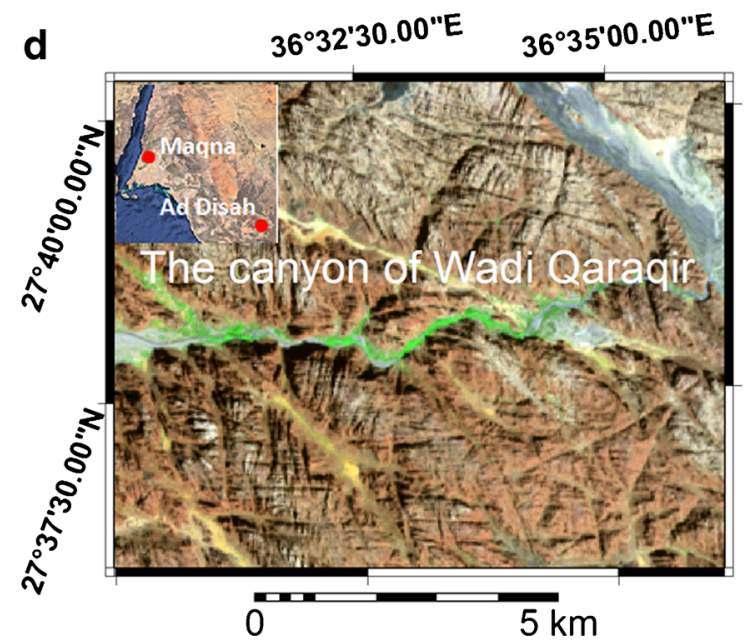

Landsat ETM+ imagery Sept 17, 1999 presented in false color composite (R:7, G 4, and B 2). d Landsat OLI imagery Sept 23, 2016 presented in false color composite (R 6, G 5, and B 3) 
1:250,000-scale geologic map of the Shaghab quadrangle (Graiger and Hanif 1989) shows that the rock bodies in the Wadi Ad Disah basin are mainly made of Paleozoic sandstone. Besides, basaltic lava overlies these sedimentary strata in small places of the wadi basin. Newton (1995) stated that:

Jabal Qaraqir is composed of a sequence of three formations: the uppermost red Rumm sandstone, the middle cream to orange coloured Quweira sandstone and the lower, massive dark red Siq sandstone and conglomerates, standing on a base of eroded Pre-Cambrian rocks. The sandstone massif is deeply eroded into precipitous pinnacles and steep-walled, narrow canyons (p. 20).

The canyons in lower reaches of Wadi Qaraqir and middle the reaches of Wadi Ghamrah contain springs. The canyon floor in lower reaches of Wadi Qaraqir is filled with alluvial sediments composing mainly of sand and fine gravels, whereas the canyon floor in middle the reaches of Wadi Ghamrah is filled with coarse gravels, pebbles, and boulders. The canyon floor in lower reaches of Wadi Qaraqir is narrow and mainly occupied by stream channels and sandbars. It is vegetated with relatively dense wetland plants, namely Phragmites and Typha. The color composites of multi-temporal Landsat images give a general impression that no major changes in the vegetation cover at the canyon floors (Fig. 7). One of the widely used indices to measure vegetation cover conditions from remotely sensed images is Normalized Difference Vegetation Index (NDVI) which is calculated from the red (RED) and nearinfrared (NIR) bands as: NDVI $=(\mathrm{NIR}-\mathrm{RED}) /(\mathrm{NIR}+$ RED). Since the relatively dense wetland plants in the canyon floor indicate to water availability, the NDVI was applied on the historic Landsat image to determine the changes in density of green vegetation "greenness" in this area. The results have shown that no major vegetation greenness changes occurred. Thus, one may conclude that changes in water supply from springs are not extreme to impose negative changes on the vegetation cover during dry summer seasons.

Each of the two canyons has two types of springs which are gravity contact springs and gravity valley side springs. Besides, in the most upper reaches of Wadi Qaraqir, close to the water divide at $27.71389^{\circ} \mathrm{N} 36.56801^{\circ} \mathrm{E}$, a gravity contact mesa (cliff) spring occurs which is called Asaad. The discharge of Asaad spring was $0.33 \mathrm{l} / \mathrm{min}$ in 2016 and the EC was $470 \mu \mathrm{mohs} / \mathrm{cm}$ (see Table 1 ). The gravity valley side springs and seepages in the canyons are emerging from the walls near their bottoms at the geographic locations $27.63367^{\circ}$ $\mathrm{N} 36.52130^{\circ} \mathrm{E}$ and $27.65732^{\circ} \mathrm{N} 36.46243^{\circ} \mathrm{E}$ (see Fig. 1). Furthermore, three gravity contact springs emerge from the streambeds of the Wadi Qaraqir and the Wadi Ghamrah at the geographic locations $27.63250^{\circ} \mathrm{N} 36.56806^{\circ} \mathrm{E}$, $27.63371^{\circ} \mathrm{N} 36.52135^{\circ} \mathrm{E}$, and $27.65884^{\circ} \mathrm{N} 36.46778^{\circ} \mathrm{E}$. The water from each gravity contact spring runs down as a small stream for hundreds of meters, and then the flowing water disappears when the infiltration rates of the alluvial deposits exceed the flow rates. Table 1 shows that the discharge of these springs varies from spring to spring and from year to year for each spring. For instance, the discharge of the Wadi Qraqir valley side spring ranges from $3.68 \mathrm{l} / \mathrm{min}$ measured in 2011 to $1.33 \mathrm{l} / \mathrm{min}$ measured in 2016. This means that the discharge in 2016 for the spring represented only $36 \%$ of its discharge in 2011. The discharge fluctuations of the springs in the region may reflect the annual recharge inconstancy to the aquifers that supplies them with water. On the other hand, it can be seen from Table 1 that water qualities of springs in the Wadi Ad Disah basin are very good, where it ranges between 420 and $730 \mu \mathrm{mohs} / \mathrm{cm}$ with small temporal changes.

\section{Al Qattar spring}

The Al Qattar is seepage in the form of water drops coming from a cave ceiling which is located at $28.87497^{\circ} \mathrm{N} 35.51168^{\circ}$ E near Az Zaytah village. The cave is formed in partially

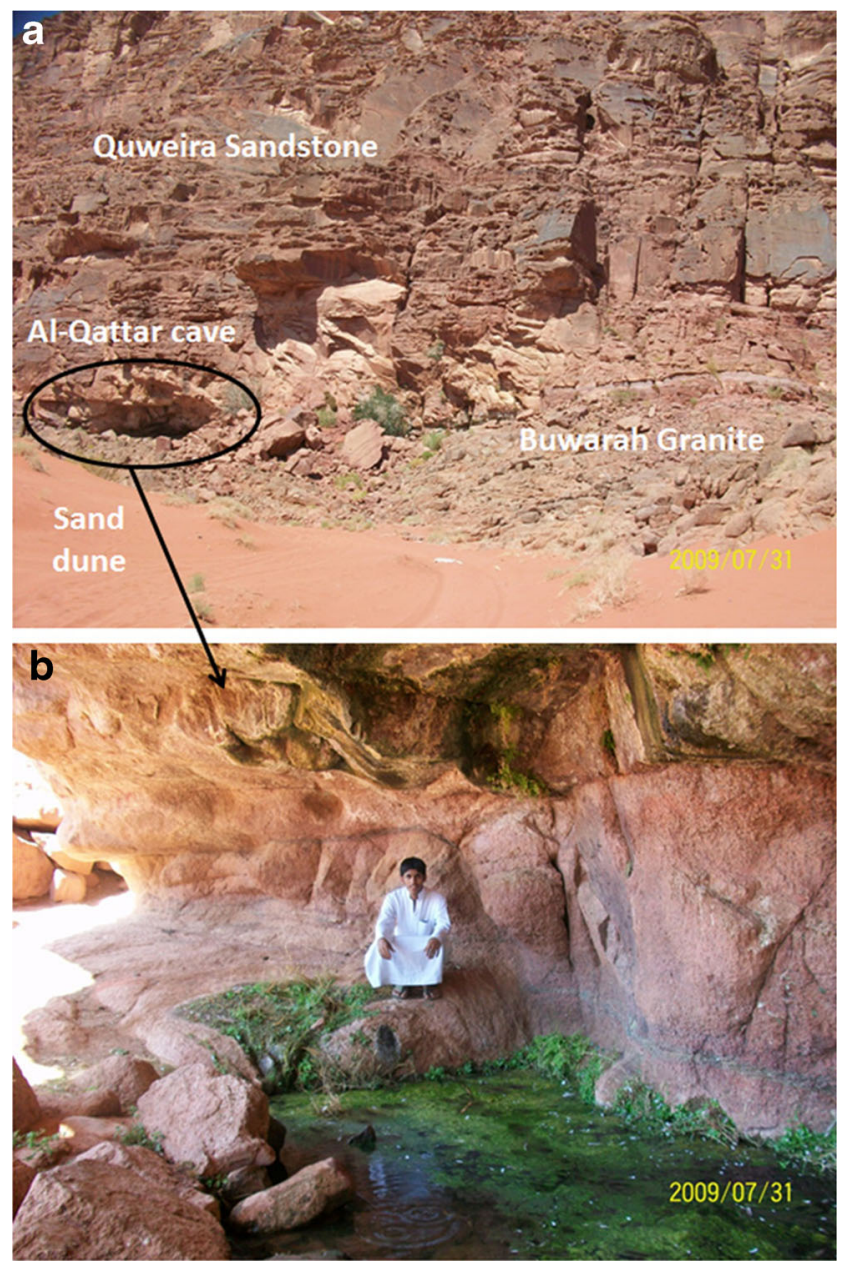

Fig. 8 a The Al Qattar cave located at $28.87497^{\circ} \mathrm{N} 35.51168^{\circ} \mathrm{E}$ near Az Zaytah village. b A natural pool excavated at the floor of The Al Qattar cave 
weathered granite rocks. A Cenozoic sandstone layer overlies the Precambrian granite bedrock (Fig. 8). In fact, parts of the cave ceiling represent a bottom of a saturated zone of an aquifer. Thus, water drops come continuously from several places in its ceiling. Indeed, the water flowing out varies from one place to another in the cave ceiling, where the highest rate found was about 100 drops per minute. The water drops feed a permanent natural pool which occupies part of the cave floor. The electrical conductivity value of collected drops of water was $300 \mu \mathrm{mohs} / \mathrm{cm}$.

\section{Summary and conclusion}

Nine springs have been identified, located, measured, and described in the northwest region of Saudi Arabia. Two springs are found near the shore of the Gulf of Aqaba which are the Ain Musa spring and the Wadi Tayyib Ism spring. Six springs have been found within the Wadi Ad Disah basin. The ninth spring has been found near the Az Zaytah village. Based on the analysis of the multi-temporal remote sensing image, interviews with local people, and the three field visits $(2009,2011$, and 2016), the nine springs are perennial. The Ain Musa spring is an artesian fissure spring, whereas the other eight are gravity type springs. Excluding the Al Qattar is seepage, the highest discharge rates were found in the Ain Musa spring and the lowest flow rate was found in the Asaad spring. The electrical conductivity values of the springs range from $300 \mu \mathrm{mohs} / \mathrm{cm}$ at Al Qattar seepage to $5300 \mu \mathrm{mohs} / \mathrm{cm}$ at the Wadi Tayyib Ism spring. However, water qualities can be described as relatively poor in the Wadi Tayyib Ism spring, medium in the Ain Musa spring, and very good in all other springs.

The discharge measurements of the Ain Musa spring revealed its constancy in 2009, 2011, and 2016. But, temporal discharge fluctuations were a characteristic of all the gravity springs in the region. The flow rate variations of the springs in the region may reflect the annual recharge inconstancy to the aquifers that supplies them with water. All springs in the region, except the Ain Musa spring, are supplied with water from unconfined aquifers which recharged by current low and highly variable precipitation and runoff.

Finally, the lack of geomorphological, hydrological, climatic, and hydrogeological data and studies of the northwest part of Saudi Arabia prevents gaining a deep understanding of spring characteristics in the region. Thus, this study has contributed with new basic information on springs found in an area with scarce information about the influencing factors. Therefore, studies on aquifer characteristics, recharge rates of aquifers, effective precipitation, etc. are badly needed to be carried out in the region to get detail knowledge of each spring's characteristics.
Open Access This article is distributed under the terms of the Creative Commons Attribution 4.0 International License (http:// creativecommons.org/licenses/by/4.0/), which permits unrestricted use, distribution, and reproduction in any medium, provided you give appropriate credit to the original author(s) and the source, provide a link to the Creative Commons license, and indicate if changes were made.

\section{References}

Ady J (1991) Othman Llewellyn's Arabia: a guide to mountains of unusual beauty. J Saudi Arab Nat Hist Soc 3:44-48 Retrieved from http://nwrc.gov.sa/NWRC ARB/mzyd files/2-1991-018.pdf

Al Tokhais AS, Rausch R (2008) The hydrogeology of Al Hassa springs. The 3rd International Conference on Water Resources and Arid Environments and the 1st Arab Water Forum, Riyadh, Saudi Arabia. Retrieved from https://www.researchgate.net/publication/ 267386708 The Hydrogeology of Al_Hassa_Springs

Al-Hawas IA (2002) Irrigation water quality evaluation of Al-Hassa springs and its predictive effects on soil properties. Pak J Biol Sci 5:651-655

Aljohani KM (2014) Historical and current status of springs in the Kingdom of Saudi Arabia (unpublished MSc Thesis). University of South Florida, Retrieved from http://scholarcommons.usf.edu/ cgi/viewcontent.cgi?article $=6172 \&$ context $=$ etd

Al-Kahtani MA, Youssef AM, Fathi AA (2007) Ecological studies on AlKhadoud Spring, Al-Hassa, Saudi Arabia. Pak J Biol Sci 10:40634068

Al-Laboun A, Al-Quraishi A, Zaman H, Benaafi M (2014) Reservoir characterization of the Burqan Formation sandstone from Midyan Basin, Northwestern Saudi Arabia. Turk J Earth Sci 23:204-214

Almazroui M (2011) Calibration of TRMM rainfall climatology over Saudi Arabia during 1998-2009. Atmos Res 99:400-414

Al-Naeem AA (2008) Hydrochemical processes and metal composition of Ain Umm-Sabah natural spring in Al-Hassa Oasis Eastern Province, Saudi Arabia. Pak J Biol Sci 11:244-249

Aloufi A, Amr MZ (2015) Freshwater snails of Tabuk region, Northern Saudi Arabia. Jordan J Biol Sci 8:243-246

Al-Taani AA, Batayneh A, Mogren S, Nazzal Y, Ghrefat H, Zaman H, Elawadi E (2013) Groundwater quality of coastal aquifer systems in the Eastern Coast of the Gulf of Aqaba, Saudi Arabia. J Appl Sci Agric 8:768-778

Bani-Domi M (2005) Trend analysis of temperatures and precipitation in Jordan. Umm Al-Qura Univ J Educ, Soc Sci Humanit 17:14-36

Bazuhair AS, Hussein MT (1990) Springs in Saudi Arabia. JKAU: Earth Sci 3:251-258

Bramkamp RA, Brown GF, Holm DA, Layne NM Jr (1963) Geology the Wadi As Sirhan Quadrangle, Kingdom of Saudi Arabia, scale 1: 500000. USGS, Washington D.C

Brown SK (2007) The hunt for the Valley of Lemuel. J Book Mormon Stud 16:64-73

Brown GF, Jackson RO, Bogue RG, Elberg EL Jr (1963) Geology of the Northwestern Hijaz Quadrangle, Kingdom of Saudi Arabia, scale 1: 500000. USGS, Washington D.C

Brown GF, Schmidt DL, Huffman AC (1989) Geology of the Arabian Peninsula, Shield Area of Western Saudi Arabia, US Geological Survey Professional Paper 560-A

Bryan K (1919) Classification of springs. J Geol 27:522-561 Retrieved from http://www.jstor.org/stable/30058415

Clark MD (1987) Geologic map of the Al Bad' Quadrangle scale 1:250, 000, sheet 28A. Saudi Arabian Ministry of Petroleum and Mineral Resources, Jeddah

FAO (2009) Groundwater management in Saudi Arabia: draft synthesis report, Retrieved from http:/www.groundwatergovernance.org/ 
fileadmin/user_upload/groundwatergovernance/docs/Country_ studies/Saudi_Arabia_Synthesis_Report_Final_Morocco Synthesis_Report_Final_Groundwater_Management.pdf

Fathi AA, Al-Kahtani MA (2009) Water quality and planktonic communities in Al-Khadoud Spring, Al-Hassa, Saudi Arabia. Am J Environ Sci 5(3):434-443

General Commission for Survey (2012) Map of Saudi Arabia scale 1: 10000000, Retrieved from http:/geoportal.sa/GCS/WebPages/ DocumentViewer/DocumentDownload/default.aspx?tabid=General

Ghrefat H, Nazzal Y, Batayneh A, Zumlot T, Zaman H, Elawadi E, Laboun A, Mogren S, Qaisy S (2014) Geochemical assessment of groundwater contamination with special emphasizes on fluoride, a case study from Midyan Basin, northwestern Saudi Arabia. Environ Earth Sci 71:1495-1505

Goudie A, Wilkinson J (1977) The warm desert environment. Cambridge University Press, Cambridge

Graiger DJ, Hanif MR (1989) Geologic map of the Shaghab Quadrangle scale 1:250,000, sheet 27B. Saudi Arabian Ministry of Petroleum and Mineral Resources, Jeddah

Hall M, Miller AG, Llewellyn O, Abbasi TM, Al-Harbi RJ, Al-Wetaid AH, Al-Shammari KF (2010) A conservation assessment of Douepea Arabica (Brassicaceae): a critically endangered plant species from Saudi Arabia. Oryx 44:547-550

Hasanean H, Almazroui M (2015) Rainfall: features and variations over Saudi Arabia, a review. Climate 3:578-626

Hughes GW, Perincek D, Abu-Bshait A, Jarad A (1999) Aspects of Midyan geology, Saudi Arabian Red Sea. Saudi Aramco J Technol, pp. 12-42. Retrieved from https://www.researchgate.net/ publication/265363508 ASPECTS O F MIDYAN GEOLOGY SAUDI_ARABIAN_RED_SEA

Jones KR (1981) Arid zone hydrology for agricultural development. FAO Irrigation and Drainage Paper 37, Food and Agriulture Organization of the Uninted Nations, Rome
Kalbus E, Oswald S, Wang W, Kolditz O, Engelhardt I, Al-Saud MI, Rausch R (2011) Large scale modeling of the groundwater resources on the Arabian platform. Int J Water Res Arid Envi 1:38-47

Llewellyn OA, Hall M, Miller AG, Al-Abbasi TM, Al-Wetaid AH, AlHarbi RJ, Al-Shammari KF, Al-Farhan A (2010) Important plant areas in the Arabian Peninsula: 1. Jabal Qaraqir. Edinb J Bot 67: $37-56$

Ministry of Agriculture and Water (1984) Water atlas of Saudi Arabia. Ministry of Agriculture and Water, Riyadh

Ministry of Water and Electricity (2000) Monthly rainfall data in Saudi Arabia during the period 1985-2000. Ministry of Water and Electricity, Riyadh

Newton SF (1995) Kingdom of Saudi Arabia. In: Scott DA (ed) A directory of wetlands in the Middle East. Gland and Slimbridge, IUCN and IWRB Retrieved from https:/www.wetlands.org/publications/ directory-of-wetlands-in-the-middle-east/

Potter GD (1999) A new candidate in Arabia for the "Valley of Lemuel". J Book Mormon Stud 8:54-63

The National Center for Atmospheric Research (2008) Lab annual report, priority 2: investigating the interactions of the atmosphere, the broader earth system, and human society. Retrieved from http:// www.nar.ucar.edu/2008/RAL/goal_1/priority_2.php

Trent VA, Johnson RF (1968) Reconnaissance mineral and geologic investigations in the $\mathrm{Al}$ Bad' Quadrangle, investigations in the $\mathrm{Al}$ Bad' Quadrangle, Aqaba Area, Saudi Arabia, open file report 68275, United States Geological Survey

Tubbs RE Jr, Fouda HGA, Afifi AM, Raterman NS, Hughes GW, Fadolalkarem YK (2014) Midyan Peninsula, northern Red Sea, Saudi Arabia: Seismic imaging and regional interpretation. GeoArabia 19:165-184

Zumlot T, Batayneh A, Zaman H, Ghrefat H, Mogren S, Nazzal Y, Elawadi E, Elwaheidi M (2016) Statistical analysis of different chemical elements in groundwater of Northwestern Saudi Arabia. J Geol Soc India 87:469-475 